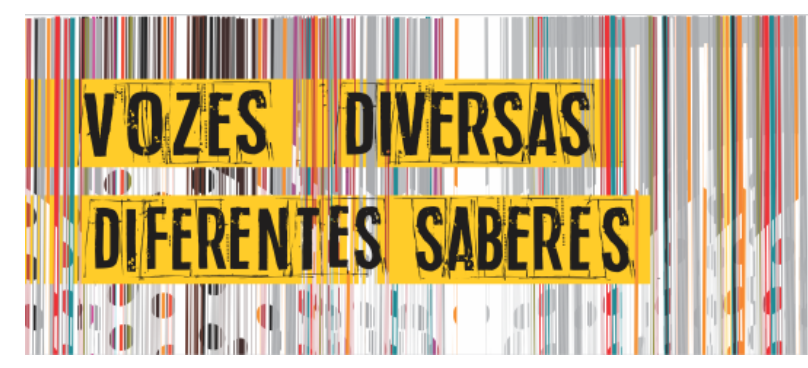

SALÃO DE

\begin{tabular}{|l|l|}
\hline Evento & $\begin{array}{l}\text { Salão UFRGS 2018: SIC - XXX SALÃO DE INICIAÇÃO CIENTÍFICA } \\
\text { DA UFRGS }\end{array}$ \\
\hline Ano & 2018 \\
\hline Local & Campus do Vale - UFRGS \\
\hline Título & $\begin{array}{l}\text { Avaliação da Partição de Fósforo Aplicada na Produção de } \\
\text { Aço: Modelos Matemáticos e Termodinâmica Computacional }\end{array}$ \\
\hline Autor & JÚLIA GIACOMET BERGOZZA \\
\hline Orientador & WAGNER VIANA BIELEFELDT \\
\hline
\end{tabular}




\section{Avaliação da Partição de Fósforo Aplicada na Produção de Aço: Modelos Matemáticos e Termodinâmica Computacional}

Júlia Giacomet Bergozza

\section{Resumo}

Com o aumento da produção de aço no Brasil e no mundo - uma alta de 9,9\% ante 2016, chegando a atingir um marco de 34,3 milhões de toneladas [1] - é visível que uma melhor qualidade dessa commodity tornou-se necessária. Por conseguinte, vem sendo realizados estudos sobre a desfosforação do aço, visto que este elemento, quando em altas quantidades, tem como característica a fragilidade a frio. Este trabalho foi realizado com fins de reconsiderar os estudos feitos sobre os modelos matemáticos de desfosforação e os resultados do programa de simulação termodinâmica FactSage v.7.2 e, compara-los com dados de uma indústria siderúrgica. Como resultado, foi observado que: nenhum dos modelos matemáticos analisados neste artigo apresentou uma correlação ótima para a indústria siderúrgica trabalhada. É percebível que um estudo aprofundado acerca da previsão da partição de fósforo em aciarias elétricas deve ser realizado.

Autora: Júlia Giacomet Bergozza

Orientador: Wagner Viana Biefeldt

Universidade Federal do Rio Grande do Sul (UFRGS) 